University of Wollongong

Research Online

Faculty of Science - Papers (Archive)

Faculty of Science, Medicine and Health

$15-11-2005$

\title{
Evidence of Reduced Measurement Uncertainties from an FTIR Instrument Intercomparison At Kiruna, Sweden
}

\author{
A. Meier \\ University of Wollongong \\ Clare Paton-Walsh \\ University of Wollongong, clarem@uow.edu.au \\ C. Bell \\ National Physical Laboratory, UK \\ T. Blumenstock \\ University of Karlsruhe, Germany \\ F. Hase \\ University of Karlsruhe, Germany
}

See next page for additional authors

Follow this and additional works at: https://ro.uow.edu.au/scipapers

Part of the Life Sciences Commons, Physical Sciences and Mathematics Commons, and the Social and Behavioral Sciences Commons

\section{Recommended Citation}

Meier, A.; Paton-Walsh, Clare; Bell, C.; Blumenstock, T.; Hase, F.; Goldman, A.; Steen, A.; Kift, R.; Woods, P.; and Kondo, Y.: Evidence of Reduced Measurement Uncertainties from an FTIR Instrument Intercomparison At Kiruna, Sweden 2005.

https://ro.uow.edu.au/scipapers/23

Research Online is the open access institutional repository for the University of Wollongong. For further information contact the UOW Library: research-pubs@uow.edu.au 


\title{
Evidence of Reduced Measurement Uncertainties from an FTIR Instrument Intercomparison At Kiruna, Sweden
}

\author{
Abstract \\ We report the results of an intercomparison of vertical column amounts of $\mathrm{HCl}, \mathrm{HF}, \mathrm{N} 2 \mathrm{O}, \mathrm{HNO} 3, \mathrm{CH} 4, \mathrm{O} 3$, \\ $\mathrm{CO} 2$ and N2 derived from the spectra recorded by two ground-based FTIR spectrometers operated side- \\ by-side using the sun as a source. The procedures used to record spectra and derive vertical column \\ amounts followed the format of previous instrument intercomparisons organised by the Network for \\ Detection of Stratospheric Change (NDSC), but the level of agreement achieved was significantly better \\ than for previous intercomparisons. For most gases the differences were typically $1 \%$ or less, with at least \\ one of the five datasets showing no statistically significant difference between the results from different \\ instruments. Principal exceptions were $\mathrm{HNO} 3$ and $\mathrm{CO} 2$ when measured on the Mercury Cadmium \\ Telluride (MCT) detectors. For these gases differences of between $2 \%$ and $3 \%$ were more typical. We \\ present evidence that these larger differences are due to the effects of detector non-linearity and show \\ that by applying an established non-linearity correction method the typical level of agreement can be \\ improved to better than $1 \%$ for these gases. We suggest that the improved level of agreement achieved \\ during this intercomparison is indicative of the current state of the art within the NDSC infra-red working \\ group and is a result of improved understanding of the importance of critical alignment parameters and \\ newly developed techniques to characterise the spectrometers' performance.

\section{Disciplines} \\ Life Sciences | Physical Sciences and Mathematics | Social and Behavioral Sciences

\section{Publication Details} \\ This article was originally published as Meier, A, Paton-Walsh, C, Bell, W et al, Evidence of Reduced \\ Measurement Uncertainties from an FTIR Instrument Intercomparison At Kiruna, Sweden, Journal of \\ Quantitative Spectroscopy \& Radiative Transfer, 96(1), 2005, 75-84. Copyright Elsevier 2005. Original \\ journal available here.

\section{Authors} \\ A. Meier, Clare Paton-Walsh, C. Bell, T. Blumenstock, F. Hase, A. Goldman, A. Steen, R. Kift, P. Woods, and \\ Y. Kondo
}




\title{
Evidence of Reduced Measurement Uncertainties from an FTIR Instrument Intercomparison At Kiruna, Sweden
}

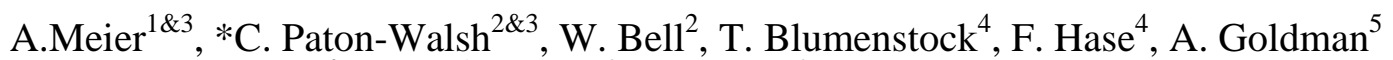
Å. Steen ${ }^{1}$, R. Kift ${ }^{2}$, P. Woods ${ }^{2}$ and Y. Kondo ${ }^{6}$.

${ }^{1}$ Swedish Institute of Space Physics (IRF), Kiruna

${ }^{2}$ National Physical Laboratory (NPL), Teddington, England.

${ }^{3}$ Department of Chemistry, University of Wollongong, Australia.

${ }^{4}$ Institute of Meteorology and Climate Research, Forschungszentrum Karlsruhe and University of Karlsruhe, Germany

${ }^{5}$ Department of Physics, University of Denver, Colorado, USA.

${ }^{6}$ University of Tokyo.

(* Corresponding Author)

\begin{abstract}
.
We report the results of an intercomparison of vertical column amounts of $\mathrm{HCl}, \mathrm{HF}, \mathrm{N}_{2} \mathrm{O}$, $\mathrm{HNO}_{3}, \mathrm{CH}_{4}, \mathrm{O}_{3}, \mathrm{CO}_{2}$ and $\mathrm{N}_{2}$ derived from the spectra recorded by two ground-based FTIR spectrometers operated side-by-side using the sun as a source. The procedures used to record spectra and derive vertical column amounts followed the format of previous instrument intercomparisons organised by the Network for Detection of Stratospheric Change (NDSC), but the level of agreement achieved was significantly better than for previous intercomparisons.
\end{abstract}

For most gases the differences were typically $1 \%$ or less, with at least one of the five datasets showing no statistically significant difference between the results from different instruments. Principal exceptions were $\mathrm{HNO}_{3}$ and $\mathrm{CO}_{2}$ when measured on the Mercury Cadmium Telluride (MCT) detectors. For these gases differences of between 2\% and 3\% were more typical. We present evidence that these larger differences are due to the effects of detector non-linearity and show that by applying an established non-linearity correction method the typical level of agreement can be improved to better than $1 \%$ for these gases.

We suggest that the improved level of agreement achieved during this intercomparison is indicative of the current state of the art within the NDSC infra-red working group and is a result 
of improved understanding of the importance of critical alignment parameters and newly developed techniques to characterise the spectrometers’ performance.

Keywords: FTIR, intercomparison, atmospheric spectroscopy, trace gases, remote sensing

\section{Introduction}

The Network for Detection of Stratospheric Change (NDSC) [1, 2] is a global network of ground-based remote sensing stations, using predominantly spectroscopic techniques to measure the chemical composition of the atmosphere. Originally focused on the detection and characterisation of long-term trends in stratospheric ozone and gases involved in ozone chemistry, the NDSC now also provides measurements of predominantly tropospheric trace gases as well as a coordinated resource for comparison and calibration of satellite-borne instruments for atmospheric composition measurements. Further details can be obtained from the NDSC web site, http://www.ndsc.ws.

In order to ensure the quality of the measurements, the NDSC stipulates a validation protocol [3] to be followed by all instruments, of which the intercomparison of instruments forms a pivotal role. Previous NDSC FTIR instrument intercomparisons[4-6] have yielded typical levels of agreement of $1-2 \%$ for tropospheric gases such as $\mathrm{N}_{2} \mathrm{O}$ and $\mathrm{CO}_{2}$, and of $2-3 \%$ for stratospheric compounds such as $\mathrm{HCl}, \mathrm{HNO}_{3}$ and $\mathrm{HF}$, with some instances of worse levels of agreement. The results of these earlier intercomparisons underlined the importance of a thorough knowledge of the spectrometer's instrumental line shape (ILS). More recently, better techniques have been developed to characterise the ILS using low-pressure gas cells, which have been adopted by all members of the infrared working group of the NDSC[7].

\section{Format of the Intercomparison}


The FTIR intercomparison described here was conducted at the Swedish Institute of Space Physics (IRF Institutet för Rymd-Fysik), Kiruna during March 1998. The facility is located at $67.84^{\circ} \mathrm{N}, 20.41^{\circ} \mathrm{E}, 419 \mathrm{~m}$ above mean sea level, $8 \mathrm{~km}$ east of Kiruna town centre. The BRUKER $120 \mathrm{HR}$ interferometer permanently installed at IRF and operated in collaboration with the Institute of Meteorology \& Climate Research, Karlsruhe (IMK) and the University of Nagoya (STEL), Japan was compared with the mobile BRUKER 120M operated by the National Physical Laboratory (NPL). The two spectrometers were operated on the same floor within 5m of each other. Spectra were recorded simultaneously on both instruments using a single forward or backward scan.

The intercomparison consisted of an "open” phase, when the performance of the instruments and the results of analysis of the spectra could be openly discussed, followed by a "blind" phase when no exchange of information was permitted between the two groups. The results of analysis of spectra recorded in this blind phase were sent to an independent referee (A. Goldman) for collation and comparison.

\section{Preparation of the Spectrometers}

After the mobile spectrometer had been re-assembled, the alignment of each instrument was tested by placing a low-pressure of $\mathrm{N}_{2} \mathrm{O}$ or $\mathrm{HBr}$ in a glass cell with $\mathrm{KBr}$ windows in the beam of the spectrometer. Spectra were recorded using an internal infra-red source or the sun and analysed using LINEFIT[7]. The results showed that the Bruker 120 HR located at Kiruna had a near perfect instrument line-shape (ILS), with negligible residual phase error and with the modulation efficiency at maximum optical path difference being nearly $100 \%$ of the theoretical value expected for ideal alignment. This ratio was between $85 \%$ and $90 \%$ for the NPL Bruker $120 \mathrm{M}$ spectrometer, with a very small residual phase error. This result is typical of what can be achieved with this type of mobile spectrometer and the participants were therefore satisfied that 
the spectrometers were well aligned, free from unusual problems and ready for the intercomparison to begin.

\section{Spectral Analysis}

Vertical column amounts were derived from each individual spectrum by iteratively adjusting the concentration of the target gas in a simulated spectral interval until the difference between measured and simulated spectrum was minimised. The simulated spectrum used a layered model of the atmosphere, with the pressure, temperature and an initial concentration for each gas assigned for every layer. The iterative fitting algorithm was constrained to allow only a scaling of the concentration profile for each gas (i.e. the concentration of the gas was multiplied by a single factor applied to all layers of the model). Both groups used an identical algorithm to perform this non-linear iterative fitting, namely the SFIT spectral fitting code, version 1.9e.

A large effort was made to ensure that the ancillary data and spectral fitting parameters used by both groups were identical. The pressure and temperature (PT) data was taken from locally launched sondes when available, or from the European Community Medium-range Weather Forecast model (ECMWF). This was then splined with a standard sub-arctic PT profile to produce a PT profile to be used by both groups. Discussions about the best method for producing these PT profiles led to a realisation that the ray-tracing analysis was not capturing the effects of strong temperature inversions in the boundary layer, which were a common atmospheric condition at Kiruna. A method of correcting this problem by approximation was agreed upon for use during the intercomparison. Improvements in the ray-tracing analysis for the airmass calculations to correct this problem were made at a later date [8].

The initial concentration profiles for each day were generated by adjusting a standard set by a subsidence factor [9] which was estimated from ECMWF potential vorticity maps and using a tropopause height estimated from the PT profile [10]. The use of a single set of reference concentration profiles for all days (as had been done in earlier intercomparisons) was not 
practical because the airmass above Kiruna in spring can be highly variable due to the effects of subsidence. Ozone sonde data from Sodankylae or Esrange was used for the a-priori ozone profiles on all days.

The exact frequency range or "micro-window" to be used for retrieving each gas and which interfering gases should be adjusted and which fixed was also agreed before the analysis started. Details of the chosen micro-windows are given in Table 1.

At the beginning of the blind phase of the intercomparison it was still unclear how best to ensure consistency in the treatment of non-linearity effects. As a result no corrections were made, and the analysis of this known problem was left until after the blind results were known.

\section{Results}

Once the referee had received all results from both groups, the derived vertical columns were released for both groups to see. The results were consistent with those seen in the open phase of the intercomparison: the level of agreement was generally good, with the most significant differences seen in gases derived from spectra recorded on the MCT detectors.

In order to determine whether or not a systematic bias existed between the results derived from spectra recorded by the two different instruments, a thorough statistical analysis was undertaken. The intercomparison had yielded approximately 12 coincident pairs of derived column amounts for each gas in each of the micro-windows analysed on each of the five days of blind intercomparison. For each coincident pair the vertical column amount of a gas derived from the IRF spectrum was subtracted from the equivalent NPL column to yield a difference. Thus a set of 12 differences was calculated for each molecule on each measurement day. The "paired $t$-test" was then applied to each of these sets of differences to test the hypothesis that there was no systematic bias between the results from the two instruments. If this hypothesis is true, then the set of differences will be a sample, size $n=12$, from a normally distributed population with mean zero [11]. 
The $t$-test statistic is

$$
t=-\frac{\mathrm{d}}{\mathrm{S}_{\mathrm{d}} / \sqrt{\mathrm{n}}}
$$

At the $95 \%$ confidence level, $t=1.96$, for infinite $\mathrm{n}$. If $t$ is greater than this for our sample size of $\mathrm{n}=12$, then the hypothesis is in doubt, and we conclude that it is most probable that a systematic difference exists between the two instruments. The mean difference for each set of data is quoted with the standard error (SE), defined as:

$\mathrm{SE}=\mathrm{S}_{\mathrm{d}} / \sqrt{ } \mathrm{n}$

where $\mathrm{S}_{d}$ is the standard deviation of the difference $d$.

The results are presented in Table 2.

\section{Discussion of the Results}

For all gases derived from spectra recorded on the InSb detectors the mean percentage difference over all five days was $1 \%$ or less, with the worst level of agreement for HF near the end of the intercomparison. Although both spectrometers were nominally well aligned, the imperfections in the instrument line-shape of the NPL spectrometer will have caused minor distortions of the real spectra that were not represented in the model. This is because, for the purposes of the intercomparison, an ideal line-shape was assumed for both spectrometers. The use of low-pressure gas cells for the measurement of instrument line-shapes and their use in spectral analysis is now part of the normal operating procedure for NDSC instruments. 
The mean percentage differences found over the five days for $\mathrm{HF} ; \mathrm{HCl} ; \mathrm{O}_{3}\left(\right.$ at $3040 \mathrm{~cm}^{-1}$ ); $\mathrm{O}_{3}$ (at $3045 \mathrm{~cm}^{-1}$ ); $\mathrm{CH}_{4}\left(\right.$ at $\left.2835 \mathrm{~cm}^{-1}\right) ; \mathrm{CH}_{4}\left(\right.$ at $2904 \mathrm{~cm}^{-1}$ ); $\mathrm{N}_{2} \mathrm{O}$ (at $2806 \mathrm{~cm}^{-1}$ ); $\mathrm{N}_{2} \mathrm{O}$ (at 2482 $\mathrm{cm}^{-1}$ ); $\mathrm{N}_{2}$ (at $2419 \mathrm{~cm}^{-1}$ ) and $\mathrm{CO}_{2}\left(\right.$ at $2627 \mathrm{~cm}^{-1}$ ) were $1 \% ; 0.7 \% ; 0.4 \% ; 0.1 \% ; 0.2 \% ; 0.2 \%$; $0.6 \% ; 0.1 \% ; 0.5 \%$ and $0.7 \%$ respectively.

It is important to note that although small, nearly half of the daily percentage differences seen for the various target gases were shown to be significant by the t-test, These differences, although real, are often much smaller than the differences seen between the two alternative micro-windows chosen for analysis, and more importantly much smaller than the variation seen between different days of the intercomparison. From this we may conclude that with modern techniques to characterise the performance of NDSC spectrometers, instrumental differences represent a small part of the uncertainty budget for derived column amounts. The quality of ancillary data (pressure-temperature profiles, a-priori profiles) and the consistency of analysis within different groups of the NDSC is likely to be the most significant factor in the comparability of measurements from different parts of the global network. These uncertainties in the measurements are clearly significantly smaller than the day-to-day variation in the vertical columns amounts, so that the ability to see these short-term changes is not compromised. However, when trying to detect small long-term changes in these variable quantities, it is clear that consistency of analysis throughout the years of data being analysed is critical to an accurate determination of trends.

The differences seen in column amounts of $\mathrm{HNO}_{3}$ and $\mathrm{CO}_{2}$ when measured on the Mercury Cadmium Telluride (MCT) detectors were similar to those seen during the open phase of the intercomparison. For four days NPL used a $10 \mu \mathrm{m}$ long pass filter and IRF used a broader $7 \mu \mathrm{m}$ long pass filter and the IRF derived column amount for $\mathrm{CO}_{2}$ was typically $1 \%$ or $2 \%$ lower than the equivalent NPL result. Swapping the filters on the $20^{\text {th }}$ March so that NPL used a $7 \mu \mathrm{m}$ long 
pass filter and IRF used a $10 \mu \mathrm{m}$ long pass filter, resulted in a 3\% difference in the other direction. (A broader optical filter results in a higher solar flux reaching the detector, increasing the non-linearity in the MCT detector and causing an underestimation of the total column amounts retrieved.)

\section{MCT Detector Non-Linearity}

A perfectly linear detector should produce a spectrum with all saturated absorption features at zero, because there is no radiation of these wavelengths reaching the detector. Non-linearity is common in Mercury Cadmium Telluride (MCT) detectors and tends to result in saturated absorption features being positively offset from the zeros level. These effects were visible in the spectra from both instruments and were estimated to be in the order of $3 \%$ for the IRF instrument (which used the NDSC standard $7 \mu \mathrm{m}$ long pass filter) and 1.5\% for the NPL instrument (which used a narrower $10 \mu \mathrm{m}$ long pass filter) for solar zenith angles of about 75 degrees. No account was made for these non-linearities in the analysis because we had not established a technique that we were confident would be consistent for both groups before the start of the blind phase of the intercomparison.

In a final stage of the intercomparison an attempt was made to correct for the effects of nonlinearity on the MCT detectors to see if we could understand and consequently eliminate the differences in derived vertical column amounts of $\mathrm{HNO}_{3}$ and $\mathrm{CO}_{2}$. Non-linearity corrections were made for each spectrum using the method described by Abrams[12]. In a separate exercise it was demonstrated that the Abrams method was consistent with the more mathematically precise method proposed by Keens [13]. It was not possible to use the Keens method with the digitally filtered high-resolution spectra recorded in the intercomparison. 
After correcting for non-linearity the spectra were again analysed for column amounts of $\mathrm{HNO}_{3}$ and $\mathrm{CO}_{2}$. After non-linearity corrections were made, the level of agreement improved significantly with differences in derived $\mathrm{HNO}_{3}$ columns less than $1.0 \%$ in all cases. Differences in $\mathrm{CO}_{2}$ columns after non-linearity correction were typically less than $0.5 \%$ except for $20^{\text {th }}$ March when the difference was 1.5\%.

\section{Conclusions}

The intercomparison results revealed typical differences of $1 \%$ or less for trace gases derived from spectra recorded on the InSb detectors. For the MCT spectra typical differences of $2-3 \%$ could be reduced significantly if the Abrams method was used to correct for detector nonlinearity. Further reductions in the differences can be expected when the measured instrument line-shape is included in the model for the simulated spectrum used in the fitting algorithm. We conclude that typical instrumental uncertainties of $1 \%$ or less can be expected from instruments within the NDSC infrared working group which have implemented all the recommended techniques for alignment and instrument characterisation. This represents a minor component of the uncertainty budget of the whole retrieval process. Further effort should concentrate on ensuring consistency in the details of the spectral fitting parameters and ancillary data used by each group in the global network, particularly the choice of spectral fitting region and the treatment of interfering gases.

Acknowledgements. The authors would like to thank the EU-funded Atmospheric Research Programme (MRI/AFP) at the Swedish Institute of Space Physics in Kiruna and their collaboration partners in Karlsruhe and Nagoya; the UK Department of Environment; the NASA Upper Atmospheric Research program; the National Science Foundation; the Esrange and Sodankylae sounding sites and the ECMWF for use of ozone sonde and pressure-temperature 
profiles; the ILAS validation group for funding additional balloon soundings at Esrange; the Esrange and Sodankylae staff for carrying out the balloon soundings, and the NDSC-IRWG community.

\section{References}

1. Kurylo, M.J., Proceedings of SPIE The International Society for Optical Engineering, Remote Sensing of Atmospheric Chemistry, 1991, 1491, 168-174. Network for the detection of stratospheric change (NDSC). in SPIE The International Society for Optical Engineering, Remote Sensing of Atmospheric Chemistry. 1991.

2. Kurylo, M.J. and R. Zander. The NDSC - its status after ten years of operation. in International Quadrennial Ozone Symposium. 2000. Sapporo, Japan.

3. Kurylo, M.J., Network for the Detection of Stratospheric Change (NDSC): Validation Protocol; Appendix IV: Infrared Instruments (FTIR),. 1997.

4. $\quad$ Griffith, D.W.T., et al., Intercomparison of NDSC ground-based solar FTIR measurements of atmospheric gases at Lauder, New Zealand. Journal of Atmospheric and Oceanic Technology, 2003. 20(8): p. 1138-1153.

5. Walsh, C.P., et al., An uncertainty budget for ground-based Fourier transform infrared column measurements of $\mathrm{HCl}, \mathrm{HF}, \mathrm{N2O}$, and HNO3, deduced from results of side-by-side instrument intercomparisons. Journal of Geophysical Research-Atmospheres, 1997. 102(D7): p. 8867-8873.

6. Goldman, A., et al., Network for the detection of stratospheric change fourier transform infrared intercomparison at Table Mountain Facility, November 1996. Journal of Geophysical Research-Atmospheres, 1999. 104(D23): p. 30481-30503.

7. Hase, F., T. Blumenstock, and C. Paton-Walsh, Analysis of the instrumental line shape of high-resolution Fourier transform IR spectrometers with gas cell measurements and new retrieval software. Applied Optics, 1999. 38(15): p. 3417-3422.

8. Meier, A., et al., Improvements to Air Mass Calculations from Ground-Based Infrared Measurements. Journal of Quantitative Spectroscopy and Radiative Transfer, 2004. 83: p. 109-113.

9. Toon, G.C., et al., Evidence for subsidence in the 1989 Arctic Winter Stratosphere from airborne infrared composition measurements. Journal of Geophysical Research, 1992. 97: p. 7963-7970.

10. Meier, A. Determination of atmospheric trace gas amounts and corresponding natural isotopic ratios by means of ground-based FTIR spectroscopy in the high arctic. in Reports on Polar Research. 1997. Bremerhaven.

11. Chatfield, C., Statistics for Technology. 3rd ed. 1983, New York: Chapman and Hall.

12. Abrams, M.C., G.C. Toon, and R.A. Schindler, Practical example of the correction of Fourier transform spectra for detector non linearity. Applied Optics, 1994. 33: p. 63076314.

13. Keens, A., Corrections of non-linearities in Detectors in Fourier Transform Spectroscopy. 1999: United States, Patent No 4927269. 
Corresponding Author:

C. Paton-Walsh, National Physical Laboratory, Queens Road, Teddington, Middlesex, TW11 OLW, England. Now at Department of Chemistry, University of Wollongong, Wollongong, NSW 2522, Australia. (e-mail clarem@uow.edu.au). Telephone +61 24221 3196, Fax: +61 242214287.

A. Meier, Swedish Institute of Space Physics, IRF Kiruna, Sweden; Department of Chemistry, now at University of Wollongong, Wollongong, NSW 2522, Australia. (e-mail: arndt@apollolifesciences.com)

W. Bell, National Physical Laboratory, Queens Road, Teddington, Middlesex, TW11 OLW, England. Now at UK Met office (e-mail: william.bell@metoffice.com)

T. Blumenstock and F. Hase, Institute for Meteorology and Climate Research, Forschungszentrum Karlsruhe and University of Karlsruhe, Germany. (e-mail: thomas.blumenstock@imk.fzk.de; frank.hase@imk.fzk.de)

A. Goldman, Department of Physics, University of Denver, Denver, CO 80208, USA. (e-mail: agoldman@du.edu)

Å. Steen, Swedish Institute of Space Physics, IRF Kiruna, Sweden.

R. Kift, National Physical Laboratory, Queens Road, Teddington, Middlesex, TW11 OLW.

P. Woods, National Physical Laboratory, Queens Road, Teddington, Middlesex, TW11 OLW.

(email: peter.woods@npl.co.uk)

Y. Kondo, Research Center for Advanced Science and Technology, The University of Tokyo, 4-6-1 Komaba, Meguro, Tokyo 153-8904, Japan. (email: kondo@atmos.rcast.u-tokyo.ac.jp) 


\section{Tables}

TABLE 1: The observation windows agreed upon for the analysis of key molecules. The last column lists interfering molecules that were taken into account in the analysis. Molecules that were actively fitted are indicated by an (F). Molecules which were pre-scaled to a total column amount retrieved in another, interference free, microwindow and held constant in the final retrieval for species are marked (C).

\begin{tabular}{|l|c|l|}
\hline $\begin{array}{c}\text { Principal } \\
\text { Molecule }\end{array}$ & \multicolumn{1}{|c|}{$\begin{array}{c}\text { Fit Region } \\
\left(\mathrm{cm}^{-1}\right)\end{array}$} & $\begin{array}{l}\text { Other Gases Included } \\
\text { C-Const(fixed) F-Fitted }\end{array}$ \\
\hline $\mathrm{HF}$ & $4038.70-4039.18$ & $\mathrm{H} 2 \mathrm{O}(\mathrm{F}), \mathrm{CH} 4$ (F), solar (F), HDO (C) \\
\hline $\mathrm{HCl}$ & $2925.69-2926.01$ & $\mathrm{CH} 4(\mathrm{~F}), \mathrm{H} 2 \mathrm{O}(\mathrm{C}), \mathrm{NO} 2(\mathrm{C})$ \\
\hline $\mathrm{O} 3$ & $3039.75-3040.55$ & $\mathrm{CH} 4(\mathrm{~F}), \mathrm{H} 2 \mathrm{O}(\mathrm{C})$ \\
\hline $\mathrm{O} 3$ & $3045.08-3045.38$ & $\mathrm{CH} 4(\mathrm{C})$ \\
\hline $\mathrm{CH} 4$ & $2903.48-2904.20$ & $\mathrm{H} 2 \mathrm{O}(\mathrm{F}), \mathrm{HCl}(\mathrm{F}), \mathrm{HDO}(\mathrm{F}), \mathrm{O} 3(\mathrm{C})$ \\
\hline $\mathrm{CH} 4$ & $2835.53-2835.80$ & $\mathrm{HDO}(\mathrm{C})$ \\
\hline $\mathrm{N} 2 \mathrm{O}$ & $2806.00-2806.80$ & $\mathrm{CH} 4(\mathrm{~F})$ \\
\hline $\mathrm{N} 2 \mathrm{O}$ & $2481.12-2482.50$ & $\mathrm{CO} 2(\mathrm{~F}), \mathrm{CH} 4(\mathrm{~F})$ \\
\hline $\mathrm{N} 2$ & $2417.95-2419.72$ & $\mathrm{CO} 2(\mathrm{~F}), \mathrm{N} 2 \mathrm{O}(\mathrm{F})$, solar $(\mathrm{F}), \mathrm{O} 3(\mathrm{C}), \mathrm{CH} 4(\mathrm{C})$ \\
\hline $\mathrm{HNO} 3$ & $867.00-869.30$ & $\mathrm{OCS}(\mathrm{C}), \mathrm{NH} 3(\mathrm{C})$ \\
\hline $\mathrm{HNO} 3$ & $872.25-874.80$ & $\mathrm{OCS}(\mathrm{C}), \mathrm{H} 2 \mathrm{O}(\mathrm{C}), \mathrm{NH} 3(\mathrm{C})$ \\
\hline $\mathrm{CO} 2$ & $2626.20-2627.06$ & $\mathrm{CH} 4(\mathrm{C})$ \\
\hline $\mathrm{CO} 2$ & $936.44-937.20$ & -- \\
\hline
\end{tabular}

Table 2: For each micro-window analysed the mean column derived from the spectra from both groups is shown for each day, along with the mean difference calculated from the pairs of coincident measurements and the standard error of this mean. The results of the $t$-test are quoted, and the mean difference between the instruments is also shown as a percentage of the mean column. If $t \geq 1.96$, (i.e. the difference is significant) then the percentage difference is shown in bold. Finally the mean percentage difference for all five days is given to highlight any biases in the results. 


\begin{tabular}{|c|c|c|c|c|c|}
\hline HF $\quad\left(4039 \mathrm{~cm}^{-1}\right)$ & $10^{\text {th }}$ March & $14^{\text {th }}$ March & $15^{\text {th }}$ March & $16^{\text {th }}$ March & $20^{\text {th }}$ March \\
\hline Mean Column (/E15) & 1.96 & 2.30 & 1.83 & 1.69 & 2.88 \\
\hline $\begin{array}{l}\text { Mean Difference } \pm \\
\text { Standard Error of mean }\end{array}$ & $\begin{array}{c}0.0106 \pm \\
0.0033\end{array}$ & $\begin{array}{c}0.0191 \pm \\
0.0050\end{array}$ & $\begin{array}{c}0.0052 \pm \\
0.0099\end{array}$ & $\begin{array}{c}0.0304 \pm \\
0.0047\end{array}$ & $\begin{array}{c}0.0411 \pm \\
0.0120\end{array}$ \\
\hline t-Test & 3.3 & 3.8 & 0.5 & 6.4 & 3.4 \\
\hline \% Difference & $0.5 \%$ & $0.8 \%$ & $(0.3 \%)$ & $1.8 \%$ & $1.4 \%$ \\
\hline \multicolumn{6}{|c|}{$\therefore$ Mean percentage difference for $\mathrm{HF}=\mathbf{1 . 0} \%$} \\
\hline $\begin{array}{l}\text { HCl }\left(2926 \mathbf{~ c m}^{-1}\right) \\
\text { Mean Column }(/ E 15)\end{array}$ & $\begin{array}{l}10^{\text {th }} \text { March } \\
5.65\end{array}$ & $\begin{array}{c}14^{\text {th }} \text { March } \\
4.34\end{array}$ & $\begin{array}{c}15^{\text {th }} \text { March } \\
4.62\end{array}$ & $\begin{array}{c}16^{\text {th }} \text { March } \\
4.50\end{array}$ & $\begin{array}{l}20^{\text {th }} \text { March } \\
4.62\end{array}$ \\
\hline $\begin{array}{l}\text { Mean Difference } \pm \\
\text { Standard Error of mean }\end{array}$ & $\begin{array}{c}0.0156 \pm \\
0.0228\end{array}$ & $\begin{array}{c}0.0072 \pm \\
0.0401\end{array}$ & $\begin{array}{c}0.0455 \pm \\
0.0219\end{array}$ & $\begin{array}{c}0.0236 \pm \\
0.0138\end{array}$ & $\begin{array}{c}0.0579 \pm \\
0.0183\end{array}$ \\
\hline t-Test & 0.7 & 0.2 & 2.0 & 1.7 & 3.2 \\
\hline \% Difference & $(0.3 \%)$ & $(0.2 \%)$ & $1.0 \%$ & $(0.5 \%)$ & $1.3 \%$ \\
\hline \multicolumn{6}{|c|}{$\therefore$ Mean percentage difference for $\mathrm{HCl}=\mathbf{0 . 7 \%}$} \\
\hline O3 $\left(3040 \mathrm{~cm}^{-1}\right)$ & $10^{\text {th }}$ March & $14^{\text {th }}$ March & $15^{\text {th }}$ March & 16th March & $20^{\text {th }}$ March \\
\hline Mean Column (/E18) & 12.6 & 8.15 & 8.68 & 9.57 & 9.93 \\
\hline $\begin{array}{l}\text { Mean Difference } \pm \\
\text { Standard Error of mean }\end{array}$ & $\begin{array}{c}-0.0710 \pm \\
0.0320\end{array}$ & $\begin{array}{c}0.0113 \pm \\
0.0059\end{array}$ & $\begin{array}{c}-0.0565 \pm \\
0.0150\end{array}$ & $\begin{array}{c}0.0209 \pm \\
0.0172\end{array}$ & $\begin{array}{c}0.0408 \pm \\
0.0164\end{array}$ \\
\hline t-Test & 2.2 & 1.9 & 3.8 & 1.2 & 2.5 \\
\hline \% Difference & $-0.6 \%$ & $(0.1 \%)$ & $-0.7 \%$ & $(0.2 \%)$ & $0.4 \%$ \\
\hline \multicolumn{6}{|c|}{$\therefore$ Mean percentage difference for $\mathrm{O} 3$ at $\left(3040 \mathrm{~cm}^{-1}\right)=0.4 \%$} \\
\hline O3 $\left(3045 \mathrm{~cm}^{-1}\right)$ & $10^{\text {th }}$ March & $14^{\text {th }}$ March & $15^{\text {th }}$ March & $16^{\text {th }}$ March & $20^{\text {th }}$ March \\
\hline Mean Column (/E18) & 12.7 & 8.09 & 8.75 & 9.70 & 9.94 \\
\hline $\begin{array}{l}\text { Mean Difference } \pm \\
\text { Standard Error of mean }\end{array}$ & $\begin{array}{c}-0.0220 \pm \\
0.0140\end{array}$ & $\begin{array}{l}0.0170 \pm \\
0.0355\end{array}$ & $\begin{array}{l}0.0108 \pm \\
0.0332\end{array}$ & $\begin{array}{l}-0.0053 \pm \\
0.0436\end{array}$ & $\begin{array}{l}-0.0052 \pm \\
0.0042\end{array}$ \\
\hline $\begin{array}{l}\text { t-Test } \\
\text { \% Difference }\end{array}$ & $\begin{array}{c}1.6 \\
-(0.2 \%)\end{array}$ & $\begin{array}{c}0.5 \\
-(0.2 \%)\end{array}$ & $\begin{array}{c}0.3 \\
(0.1 \%)\end{array}$ & $\begin{array}{c}0.1 \\
-(0.05 \%)\end{array}$ & $\begin{array}{c}1.2 \\
-(0.05 \%)\end{array}$ \\
\hline \multicolumn{6}{|c|}{$\therefore$ Mean percentage difference for $\mathrm{O} 3$ at $\left(3045 \mathrm{~cm}^{-1}\right)=0.1 \%$} \\
\hline CH4 $\left(2835 \mathrm{~cm}^{-1}\right)$ & $10^{\text {th }}$ March & $14^{\text {th }}$ March & $15^{\text {th }}$ March & $16^{\text {th }}$ March & $20^{\text {th }}$ March \\
\hline Mean Column (/E19) & 3.46 & 3.30 & 3.41 & 3.44 & 3.30 \\
\hline $\begin{array}{l}\text { Mean Difference } \pm \\
\text { Standard Error of mean }\end{array}$ & $\begin{array}{c}0.0027 \pm \\
0.0047\end{array}$ & $\begin{array}{c}-0.0055 \pm \\
0.0042\end{array}$ & $\begin{array}{c}-0.0029 \pm \\
0.0051\end{array}$ & $\begin{array}{c}-0.0037 \pm \\
0.0048\end{array}$ & $\begin{array}{c}0.0139 \pm \\
0.0050\end{array}$ \\
\hline t-Test & 0.6 & 1.3 & 0.6 & 0.8 & 2.8 \\
\hline \% Difference & $(0.1 \%)$ & $-(0.2 \%)$ & $-(0.1 \%)$ & $-(0.1 \%)$ & $0.4 \%$ \\
\hline \multicolumn{6}{|c|}{$\therefore$ Mean percentage difference for $\mathrm{CH} 4$ at $\left(2835 \mathrm{~cm}^{-1}\right)=0.2 \%$} \\
\hline CH4 $\left(2904 \mathrm{~cm}^{-1}\right)$ & $10^{\text {th }}$ March & $14^{\text {th }}$ March & $15^{\text {th }}$ March & $16^{\text {th }}$ March & $20^{\text {th }}$ March \\
\hline Mean Column (/E19) & 3.39 & 3.26 & 3.34 & 3.36 & 3.25 \\
\hline $\begin{array}{l}\text { Mean Difference } \pm \\
\text { Standard Error of mean }\end{array}$ & $\begin{array}{c}0.0013 \pm \\
0.0031\end{array}$ & $\begin{array}{c}-0.0168 \pm \\
0.0022\end{array}$ & $\begin{array}{c}-0.0114 \pm \\
0.0027\end{array}$ & $\begin{array}{c}-0.0052 \pm \\
0.0039\end{array}$ & $\begin{array}{c}-0.0019 \pm \\
0.0045\end{array}$ \\
\hline t-Test & 0.4 & 7.5 & 4.2 & 1.3 & 0.4 \\
\hline \% Difference & $(0.04 \%)$ & $-0.5 \%$ & $-0.3 \%$ & $(0.2 \%)$ & $-(0.06 \%)$ \\
\hline \multicolumn{6}{|c|}{$\therefore$ Mean percentage difference for $\mathrm{CH} 4$ at $\left(2904 \mathrm{~cm}^{-1}\right)=0.2 \%$} \\
\hline
\end{tabular}

\begin{tabular}{|l|c|c|c|c|c|}
\hline N2O (2806 $\left.\mathbf{~ c m}^{-\mathbf{1}}\right)$ & $10^{\text {th }}$ March & $14^{\text {th }}$ March & \multicolumn{1}{c|}{$15^{\text {th }}$ March } & $16^{\text {th }}$ March & $20^{\text {th }}$ March \\
Mean Column $(/ \mathrm{E} 18)$ & 6.01 & 5.86 & 6.06 & 6.09 & 5.81 \\
\hline Mean Difference \pm & $0.0500 \pm$ & $0.0322 \pm$ & $0.0284 \pm$ & $-0.0009 \pm$ & $0.0667 \pm$ \\
Standard Error of mean & 0.0117 & 0.0100 & 0.0062 & 0.0132 & 0.0112 \\
\hline t-Test & $\mathbf{4 . 3}$ & $\mathbf{3 . 2}$ & $\mathbf{4 . 6}$ & 0.1 & $\mathbf{5 . 9}$ \\
\hline \% Difference & $\mathbf{0 . 8} \%$ & $\mathbf{0 . 5 \%}$ & $\mathbf{0 . 5 \%}$ & $-(0.01 \%)$ & $\mathbf{1 . 1} \%$ \\
\hline
\end{tabular}


$\therefore$ Mean percentage difference for N2O at $\left(2806 \mathrm{~cm}^{-1}\right)=0.6 \%$

\begin{tabular}{|l|c|c|c|c|c|}
\hline N2O (2482 $\left.\mathbf{~ c m}^{-1}\right)$ & $10^{\text {th }}$ March & $14^{\text {th }}$ March & \multicolumn{1}{c}{$15^{\text {th }}$ March } & $16^{\text {th }}$ March & 20 $0^{\text {th }}$ March \\
\hline Mean Column (/E18) & 5.95 & 5.87 & 5.98 & 6.01 & 5.75 \\
\hline Mean Difference \pm & $-0.0075 \pm$ & $0.0012 \pm$ & $-0.0147 \pm$ & $-0.0139 \pm$ & $0.0073 \pm$ \\
Standard Error of mean & 0.0062 & 0.0030 & 0.0025 & 0.0243 & 0.0034 \\
\hline t-Test & 1.2 & 0.4 & $\mathbf{5 . 8}$ & 0.6 & $\mathbf{2 . 1}$ \\
\hline \% Difference & $-(0.1 \%)$ & $(0.02 \%)$ & $\mathbf{- 0 . 3 \%}$ & $-(0.2 \%)$ & $\mathbf{0 . 1} \%$ \\
\hline
\end{tabular}

$\therefore$ Mean percentage difference for N2O at $\left(2482 \mathrm{~cm}^{-1}\right)=0.1 \%$

\begin{tabular}{|c|c|c|c|c|c|}
\hline N2 $\left(2419 \mathrm{~cm}^{-1}\right)$ & $10^{\text {th }}$ March & $14^{\text {th }}$ March & $15^{\text {th }}$ March & $16^{\text {th }}$ March & $20^{\text {th }}$ March \\
\hline Mean Column (/E25) & 1.73 & 1.69 & 1.71 & 1.70 & 1.71 \\
\hline $\begin{array}{l}\text { Mean Difference } \pm \\
\text { Standard Error of mean }\end{array}$ & $\begin{array}{l}0.0060 \pm \\
0.0046\end{array}$ & $\begin{array}{c}-0.0034 \pm \\
0.0111\end{array}$ & $\begin{array}{l}0.0047 \pm \\
0.0125\end{array}$ & $\begin{array}{c}-0.0185 \pm \\
0.0102\end{array}$ & $\begin{array}{c}-0.0033 \pm \\
0.0188\end{array}$ \\
\hline t-Test & 1.2 & 0.3 & 0.4 & 1.8 & 1.8 \\
\hline \% Difference & $(0.3 \%)$ & $-(0.2 \%)$ & $(0.3 \%)$ & $-(0.5 \%)$ & $-(1.1 \%)$ \\
\hline \multicolumn{6}{|c|}{$\therefore$ Mean percentage difference for $\mathrm{N} 2=0.5 \%$} \\
\hline HNO3 $\left(868 \mathrm{~cm}^{-1}\right)$ & $10^{\text {th }}$ March & $14^{\text {th }}$ March & $15^{\text {th }}$ March & $16^{\text {th }}$ March & $20^{\text {th }}$ March \\
\hline Mean Column (/E18) & 2.43 & 2.31 & 1.64 & 1.77 & 2.72 \\
\hline $\begin{array}{l}\text { Mean Difference } \pm \\
\text { Standard Error of mean }\end{array}$ & $\begin{array}{c}0.0515 \pm \\
0.0033\end{array}$ & $\begin{array}{l}0.0609 \pm \\
0.0036\end{array}$ & $\begin{array}{c}0.0246 \pm \\
0.0054\end{array}$ & $\begin{array}{c}-0.0054 \pm \\
0.0059\end{array}$ & $\begin{array}{c}-0.0477 \pm \\
0.0077\end{array}$ \\
\hline $\mathrm{t}$-Test & 15.6 & 16.9 & 4.6 & 0.9 & 6.2 \\
\hline \% Difference & $2.1 \%$ & $2.6 \%$ & $1.5 \%$ & $-(0.3 \%)$ & $-1.8 \%$ \\
\hline \multicolumn{6}{|c|}{$\therefore$ Mean percentage difference for $\mathrm{HNO} 3$ at $\left(868 \mathrm{~cm}^{-1}\right)=1.7 \%$} \\
\hline HNO3 $\left(873 \mathrm{~cm}^{-1}\right)$ & $10^{\text {th }}$ March & $14^{\text {th }}$ March & $15^{\text {th }}$ March & $16^{\text {th }}$ March & $20^{\text {th }}$ March \\
\hline Mean Column (/E18) & 2.26 & 2.15 & 1.61 & 1.66 & 2.61 \\
\hline $\begin{array}{l}\text { Mean Difference } \pm \\
\text { Standard Error of mean }\end{array}$ & $\begin{array}{c}0.0367 \pm \\
0.0029\end{array}$ & $\begin{array}{c}0.0363 \pm \\
0.0033\end{array}$ & $\begin{array}{c}0.0407 \pm \\
0.0058\end{array}$ & $\begin{array}{c}-0.0450 \pm \\
0.0039\end{array}$ & $\begin{array}{c}-0.1070 \pm \\
0.0137\end{array}$ \\
\hline t-Test & 12.6 & 11.1 & 7.0 & 11.5 & 7.8 \\
\hline \% Difference & $1.6 \%$ & $1.7 \%$ & $2.5 \%$ & $-2.7 \%$ & $-4.1 \%$ \\
\hline \multicolumn{6}{|c|}{$\therefore$ Mean percentage difference for $\mathrm{HNO}$ at $\left(873 \mathrm{~cm}^{-1}\right)=2.5 \%$} \\
\hline $\mathrm{CO} 2\left(2627 \mathrm{~cm}^{-1}\right)$ & $10^{\text {th }}$ March & $14^{\text {th }}$ March & $15^{\text {th }}$ March & $16^{\text {th }}$ March & $20^{\text {th }}$ March \\
\hline Mean Column (/E21) & 7.79 & 7.61 & 7.62 & 7.53 & 7.67 \\
\hline $\begin{array}{l}\text { Mean Difference } \pm \\
\text { Standard Error of mean }\end{array}$ & $\begin{array}{c}0.0887 \pm \\
0.0144 \\
\end{array}$ & $\begin{array}{c}0.0599 \pm \\
0.0220\end{array}$ & $\begin{array}{c}0.0807 \pm \\
0.0180\end{array}$ & $\begin{array}{c}-0.0123 \pm \\
0.0179\end{array}$ & $\begin{array}{c}0.0367 \pm \\
0.0159\end{array}$ \\
\hline t-Test & 6.1 & 2.7 & 4.4 & 0.7 & 2.3 \\
\hline \% Difference & $1.1 \%$ & $0.8 \%$ & $1.1 \%$ & $-(0.2 \%)$ & $0.5 \%$ \\
\hline \multicolumn{6}{|c|}{$\therefore$ Mean percentage difference for $\mathrm{CO} 2$ at $\left(2627 \mathrm{~cm}^{-1}\right)=0.7 \%$} \\
\hline $\mathrm{CO} 2\left(936 \mathrm{~cm}^{-1}\right)$ & $10^{\text {th }}$ March & $14^{\text {th }}$ March & $15^{\text {th }}$ March & $16^{\text {th }}$ March & $20^{\text {th }}$ March \\
\hline Mean Column (/E21) & 7.26 & 7.20 & 7.15 & 7.06 & 6.94 \\
\hline $\begin{array}{l}\text { Mean Difference } \pm \\
\text { Standard Error of mean }\end{array}$ & $\begin{array}{c}0.0526 \pm \\
0.0232\end{array}$ & $\begin{array}{c}0.1090 \pm \\
0.0083\end{array}$ & $\begin{array}{c}0.1550 \pm \\
0.0180\end{array}$ & $\begin{array}{c}0.0662 \pm \\
0.0143\end{array}$ & $\begin{array}{c}-0.2090 \pm \\
0.0080\end{array}$ \\
\hline t-Test & 2.3 & 13.1 & 10.5 & 4.6 & 26.2 \\
\hline \% Difference & $0.7 \%$ & $1.5 \%$ & $2.2 \%$ & $0.9 \%$ & $-3.0 \%$ \\
\hline
\end{tabular}

$\therefore$ Mean percentage difference for $\mathrm{CO} 2$ at $\left(936 \mathrm{~cm}^{-1}\right)=1.7 \%$ 